\title{
The Mutual Fund Industry and the Protection of Human Rights
}

\author{
Tara L. Van Ho ${ }^{*}$ and Mohammed K. Alshaleel**
}

\begin{abstract}
This article considers the appropriate application of the United Nations Guiding Principles on Business and Human Rights (UNGP) to the mutual funds industry. Mutual funds can impact human rights by financially supporting oppressive states or abusive companies. Given the indirect nature of such impacts, along with the exclusively external management of the funds, this article argues that a unique approach to implementing the UNGP is necessary for this industry. Divided into five parts, the article outlines the governance structure of mutual funds and the expectations on states and businesses in the UNGP, before assessing the appropriateness of applying current guidance for banks and other financial actors to mutual funds. The article concludes with practical recommendations for both fund managers and states on the implementation of the UNGP in this industry.
\end{abstract}

KEYWORDS: business and human rights, mutual funds, due diligence, home state responsibility, responsibility to respect

\section{Introduction}

A staggering \$31.3 trillion USD was invested in mutual fund assets worldwide at the end of 2014. ${ }^{1}$ Mutual funds are institutional investors that pool money into a single entity run by professional managers. ${ }^{2}$ These assets financially support states through the acquisition of bonds, ${ }^{3}$

\footnotetext{
* Lecturer, University of Essex.

** Lecturer, University of Essex (mkalsh@essex.ac.uk).

${ }^{1}$ See American Investment Company Institute, 2015 Investment Company Fact Book 55th edn (2015) at 8.

${ }^{2}$ See Mobius, Mutual Funds: An Introduction to the Core Concepts (2007) at 1.

${ }^{3}$ See World Bank and International Monetary Fund, Financial Sector Assessment: A Handbook (2005) at 142.
} 
and businesses through the purchase of company shares. ${ }^{4}$ A significant form of market-based funding, ${ }^{5}$ mutual funds can have a negative, albeit indirect, impact on human rights by supporting abusive regimes or corporations. ${ }^{6}$ Mutual funds, like other 'portfolio' investments, are distinguishable from foreign direct investment (FDI) in that the latter typically involves active management and monitoring of operations, while portfolio investments do not. ${ }^{7}$ The difference between active and passive management can impact the ability of a business to manage its effects on human rights and raises novel questions about how financial actors like mutual funds can implement their human rights responsibilities.

Prominent attention has been given to the impact certain financial actors have on human rights, with allegations that banks facilitated suspicious transactions for, or otherwise financed, oppressive regimes, including South Africa's apartheid government, by providing crucial funding that ensured the continuation of human rights abuses. ${ }^{8}$ Yet, the discussion has remained

\footnotetext{
${ }^{4}$ See Collective Investment Schemes Sourcebook 2014, coll 5.2.31.

${ }^{5}$ See Haslem, Mutual Funds: Risk and Performance Analysis for Decision Making (2003) at 2; see also GarcíaMelón, et al., 'Assessing Mutual Funds' Corporate Social Responsibility: A Multistakeholder-AHP Based Methodology' (2016) 244 Annals of Operations Research 475 at 476-477.

${ }^{6}$ See Bohoslavsky, Report on Financial Complicity: Lending to States Engaged in Gross Human Rights Violations, A/HRC/28/59 (22 December 2014); Michalowski, 'No Complicity Liability for Funding Gross Human Rights Violations?' (2012) 30 Berkeley Journal of International Law 451. See also generally Banktrack, 'Human Rights Impact Briefing \#2: Drummond and Paramilitary Violence in Colombia' May 2016, available at: www.banktrack.org/ems_files/download/drummond_human_rights_impact_briefing_160525_pdf_pdf/160525_dru mmond_case_study_final.pdf [last accessed 5 December 2017].

${ }^{7}$ See Sornarajah, The International Law on Foreign Investment, 3rd edn., (2010), at 8-10.

${ }^{8}$ See e.g. In re South African Apartheid Litigation, 617 F. Supp.2d 228 (S.D.N.Y., 2009); see also Van Ho, 'Transitional Civil and Criminal Litigation' in Michalowski (ed), Corporate Accountability in the Context of Transitional Justice 52 (2013) at 60; Ramasastry, 'Secrets and Lies? Swiss Banks and International Human Rights' (1998) 31 Vanderbilt Journal of Transnational Law 325; Reichard, 'Catching the Money Train: Using the Alien Tort Claims Act to Hold Private Banks Liable for Human Rights Abuses’ (2004) 36 Case Western Reserve Journal of International Law 225 at 225; Bohoslavsky \& Rulli, "Corporate Complicity and Finance as a "Killing Agent", (2010) 8 Journal of International Criminal Law 829 at 831; Scott, 'Taking Riggs Seriously: The ATCA Case Against a Corporate Abettor of Pinochet Atrocities' 89 Minnesota Law Review 1497 (2005) at 1497-1499; Bohoslavsky and Opgenhaffen, 'The Past and Present of Corporate Complicity: Financing the Argentinian Dictatorship' (2010) 23 Harvard Human Rights Journal 157 at 191-192; 'Keeping Foreign Corruption out of the United States: Four Case Histories' Majority and Minority Staff Report, United States Senate, Permanent Subcommittee on Investigations (4 February 2010) at 2.
} 
narrow. Scholars ${ }^{9}$ and industry initiatives ${ }^{10}$ have primarily addressed the responsibility of banks and/or international financial institutions in areas of project financing and loans. ${ }^{11}$ As explained below, the targeted nature of bank loans and project financing distinguishes them from the more generalized investments of mutual funds, making the initiatives developed to date inappropriate for the mutual fund industry. The nature and purpose of mutual funds requires a different approach to human rights than what has been employed in the context of FDI, bank loans, or project financing.

The United Nations (UN) Guiding Principles on Business and Human Rights (UNGP or 'Guiding Principles') ${ }^{12}$ offer the most authoritative statement on obligations and responsibilities in the field of business and human rights. ${ }^{13}$ The UNGP rests on three 'pillars': states have an obligation to 'protect' human rights by regulating business impacts; businesses have a responsibility to respect human rights, meaning to refrain from negatively impacting human rights; and both states and businesses are expected to ensure victims have adequate access to

\footnotetext{
${ }^{9}$ See e.g. Meyersfeld and Kinley, 'Banks and Human Rights: A South African Experiment' (2015) 12 SUR 189; Michalowski, supra n 6; Bohoslavsky and Opgenhaffen, supra n 8 at 191-192; Rothe, 'Facilitating Corruption and Human Rights Violations: the Role of International Financial Institutions' 53 Crime Law and Social Change (2010) 457; Bohoslavsky, Report, supra n 6.

${ }^{10}$ See e.g. Evans, 'The Record of International Financial Institutions on Business and Human Rights' (2016) 1 Business and Human Rights Journal 327; Meyersfeld and Kinley, supra n 9; Abrahams and Wyss, Guiding to Human Rights Impact Assessment and Management (HRIAM), International Business Leaders Forum and the International Finance Corporation (2010), available at: www.unglobalcompact.org/docs/issues_doc/human_rights/GuidetoHRIAM.pdf [last accessed 20 August 2016]; Equator Principles, Equator Principles III (2013), available at www.equatorprinciples.com/resources/equator_principles_III.pdf [last accessed 5 December 2017]; Banktrack, 'Banking with Principles? Benchmarking Banks against the UN Guiding Principles on Business and Human Rights,' 2nd edn (2016), available at:

www.banktrack.org/download/bankingwithprinciples humanrights dec $2014 \mathrm{pdf} / \mathrm{hr}$ banking with principles digit al.pdf [last accessed 5 December 2017].

${ }^{11}$ But see Dowell-Jones, 'Financial Institutions and Human Rights' (2013) 13 Human Rights Law Review 423; Roca and Manta, 'Values Added: The Challenge of Integrating Human Rights into the Financial Sector' Danish Institute or Human Rights (2010) at 14.

${ }^{12}$ Ruggie, Guiding Principles on Business and Human Rights: Implementing the United Nations 'Protected Respect and Remedy' Framework, U.N. Doc. A/HRC/17/31 (2011) (UNGP).

${ }^{13}$ See e.g. Shemberg, 'New Global Standards for Business and Human Rights' (2012) 13 Business Law International 27 at 27-28.
} 
remedies when negative impacts from business activities do occur. ${ }^{14}$ This article focuses only on the first two pillars. While businesses can have positive human rights impacts, the UNGP focus on preventing, mitigating, and remediating negative impacts, finding that businesses cannot 'offset' negative impacts with positive ones. ${ }^{15}$ This article, which brings together authors with distinct expertise in mutual fund regulation and in business and human rights, follows that approach. The question is not how mutual funds can support good business practices, but what the fund, as a business, must do to limit and remediate its own, even indirect, negative human rights impacts, and how states should regulate the industry to protect human rights.

A mutual fund's impact on human rights will usually be indirect and not the result of its active participation in the violations. According to the Guiding Principles, the lack of direct participation does not excuse a mutual fund from human rights responsibilities. ${ }^{16}$ The UNGP distinguishes between those impacts that are both directly linked to a business's operations and directly caused by the business (direct impacts) and those impacts that are directly linked to the business but are indirectly caused through the conduct of third-parties the business has a relationship with (indirect impacts). ${ }^{17}$ A business's responsibilities alter slightly based on this division, but as explained below, business have responsibilities even for indirect impacts. ${ }^{18}$

The remainder of article is divided into four parts. Part 2 explains the nature and structure of mutual funds, highlighting how they differ from banks and other financial and non-

\footnotetext{
${ }^{14}$ UNGP, supra n 12 at Principle 11, 22, 25-30, and accompanying commentary; Augenstein and Kinley, 'When human rights "responsibilities" become "duties": the extra-territorial obligations of states that bind corporations' in Deva and Bilchitz (eds), Human Rights Obligations of Business: Beyond the Corporate Responsibility to Respect? 271 (2013) at 272.

${ }^{15}$ UNGP, supra n 12 at Principle 11, Commentary; Martin and Bravo, 'Introduction: More of the Same? Or Introduction of a New Paradigm?' in Martin and Bravo (eds), The Business and Human Rights Landscape: Moving Forward, Looking Back 1 (2015) at 5.

${ }^{16}$ See UNGP, supra n 12 at Principles 13 and 17, and accompanying commentary.

17 See ibid.

${ }^{18}$ See Parts 3 and 4, below.
} 
financial businesses. In discussing mutual funds, we focus on the law of the United Kingdom (UK), with some reference to the system in the United States of America (US). The UK system provides for the two most common forms of mutual funds used globally, ${ }^{19}$ allowing for a discussion that is relevant to the industry as a whole. Part 3 examines the expectations on businesses and states outlined in the Guiding Principles, with a focus on how the UNGP have been applied to financial entities. Part 4 analyses the human rights responsibilities of mutual fund investors, managers and home states, providing recommendations for fund managers and states. Part 5 concludes with practical guidance for mutual funds and states aimed at balancing the purpose of mutual funds with the responsibility on those funds to respect human rights.

\section{The Nature of Mutual Funds}

In order to understand the business and human rights implications of mutual funds, it is necessary to understand the funds' purpose and structure. This section explains both while considering the factors that set mutual funds apart from other financial actors.

\section{A. The Purpose and Nature of Mutual Funds}

Mutual funds were developed for the purpose of helping people save money in order to secure their future, ${ }^{20}$ and offer investors a diversified portfolio with limited risks, professional management, low costs and liquidity. ${ }^{21}$ Shares or units are primarily purchased either directly from the fund or through institutional channels, including mutual fund advisers and brokerage or investment firms. ${ }^{22}$ Professional management invests the fund's common pool of money in

\footnotetext{
${ }^{19}$ Russel, An Introduction to Mutual Funds Worldwide (2007) at 11.

${ }^{20}$ See Haslem, Mutual Funds: Portfolio Structures, Analysis, Management, and Stewardship (2009) at xvii.

${ }^{21}$ See Haslem, Risk and Performance Analysis, supra n 5 at 23.

${ }^{22}$ See Baker et al., Mutual Funds and Exchange-Traded Funds: Building Blocks to Wealth (2015) at 418.
} 
accordance with agreed-upon objectives. ${ }^{23}$ The funds are then required to stand ready to redeem their shares at net asset value, known as the right to exit. ${ }^{24}$ For individuals without enough funds to justify their own investments, ${ }^{25}$ and 'unsophisticated' investors, meaning those without sufficient investment experience and knowledge to appropriately weigh the risks and merits of an investment opportunity, ${ }^{26}$ mutual funds offer a viable investment opportunity. ${ }^{27}$ Because of their purpose, mutual funds are tightly regulated. ${ }^{28}$

Mutual funds principally invest in bonds, stocks, short-term money market instruments, securities, or a combination of these investments. ${ }^{29}$ The diversified portfolio is intended to limit the risk to investors by ensuring that a sudden change in any one industry or sector does not significantly alter the financial security of the fund and its worth. ${ }^{30}$ These qualities and high returns have made mutual funds competitive vehicles in the financial market, ${ }^{31}$ and have been credited with raising the financial sophistication of the population. ${ }^{32}$

The nature and purpose of mutual funds distinguish them from other financial services or market actors, including bank loans or project financing. ${ }^{33}$ A bank's loans can be made contingent on targeted human rights impact assessments, directly influencing or binding a

\footnotetext{
${ }^{23}$ See Mobius, supra $\mathrm{n} 2$ at 1.

${ }^{24}$ See Mahoney, 'Manager-investor conflicts in mutual funds' (2004) 18 Journal of Economic Perspectives 161 at 162.

${ }^{25}$ See Haslem, Portfolio Structures, supra n 20 at xvii.

${ }^{26}$ See House of Lords 3rd report 'Directive on alternative investment fund managers' The Stationery Office, 10 February 2010 at paras 101-102.

${ }^{27}$ See Haslem, Portfolio Structures, supra n 20 at 84.

${ }^{28}$ See Alshaleel, 'Undertakings for the Collective Investment in Transferable Securities Directive V: Increased Protection for Investors' (2016) 13 European Company Law 14 at 14-22.

${ }^{29}$ See Haslem, Portfolio Structures, supra n 20 at 25.

${ }^{30}$ Ibid.

${ }^{31}$ See ibid at 23 .

${ }^{32}$ See OECD, 'White paper on Governance of Collective Investment schemes' No. 88, March 2005 at 137-138.

${ }^{33}$ On the issue of loans and financing, see Bohoslavsky, 'Financial Complicity: Lending to States Engaged in Gross Human Rights Violations' (2016) 50 Texas International Law Journal 763; Banktrack, Briefing, supra n 6.
} 
corporation or state's operations. ${ }^{34}$ A mutual fund's investment is more general and is unlikely to target a specific project or action. The fungibility of the fund's support means it will be difficult to direct the money's use or track its human rights impact, ${ }^{35}$ and a fund cannot directly institute controls over the company's decision-making process. ${ }^{36}$

Even amongst generalized, market-based financing, mutual funds are again unusual in their purpose and regulation. Hedge funds operate without a single investment objective, are often designed to circumvent significant regulations, and are limited to 'sophisticated' investors, meaning those with a high net worth or sufficient investment experience. ${ }^{37}$ A sovereign wealth fund generates revenue for the state that owns it, ${ }^{38}$ and may carry the totality of the state's human rights responsibilities, ${ }^{39}$ a higher standard than the UNGP responsibility to respect. ${ }^{40}$ Mutual funds, on the other hand, are highly regulated private, corporate bodies run for commercial purposes ${ }^{41}$ which also aim to protect the interests of vulnerable investors. ${ }^{42}$ This means they are

\footnotetext{
${ }^{34}$ See Meyersfeld and Kinley, supra $n 9$.

${ }^{35}$ See Bohoslavsky, Report, supra n 6.

${ }^{36}$ See Haslem, Risk and Performance, supra n 5 at 25.

${ }^{37}$ McClean, 'The Extraterritorial Implications of The Sec's New Rule Change to Regulate Hedge Funds' (2006) 38 Journal of International Law 105 at 105-122; Atiyah and Walter, 'Hedge Funds - An Overview' (2004) 19 Butterworths Journal of International Banking and Financial Law 173 at 173-177.

${ }^{38}$ See e.g. Cummine, 'Ethical Sovereign Investors: Sovereign Wealth Funds and Human Rights' in Bohoslavsky and Letnar Černič, supra n 23, at 163, 163; Catá Backer, 'Sovereign Investing and Markets-Based Transnational Rule of Law Building: The Norwegian Sovereign Wealth Fund in Global Markets' (2013) 29 American University International Law Review 1.

${ }^{39}$ See Petroleum Fund Advisory Commission on International Law, 'Singapore Technologies Engineering: Memorandum to the Ministry of Finance' (2002), available at: etikkradet.no/en/tilradninger-ogdokumenter/recommendations/anti-personnel-landmines/singapore-technologies-engineering/ [last accessed 5 December 2017] (concluding that Norway's sovereign wealth fund cannot invest in a company involved in activities that violate the state's international treaty obligations). See also Chesterman, 'The Turn to Ethics: Disinvestment from Multinational Corporations for Human Rights Violations - The Case of Norway's Sovereign Wealth Fund" (2008) 23 American University International Law Review 577 at 584-585. But see Daelman, 'State-Owned Enterprises and Human Rights: the Qualification \& the Responsibility of the State,' in Letnar Černič and Van Ho (eds), Human Rights and Business: Direct Corporate Accountability for Human Rights 407 (2015) at 409-414. ${ }^{40}$ See UNGP, supra n 12 at General Principles ('These Guiding Principles apply ... to all business enterprises, both transnational and others, regardless of their size, sector, location, ownership and structure.').

${ }^{41}$ See Alshaleel, supra n 28 at 14-22.

${ }^{42}$ See Haslem, Portfolio Structures supra n 20 at 23.
} 
subject to the UNGP responsibility to respect, but there are unique considerations in terms of how funds address their responsibilities and the role of states in regulating the industry.

\section{B. The Structure and Operations of Mutual Funds}

\section{(i) The primary forms of mutual funds}

There are two primary organizational forms for mutual funds. ${ }^{43}$ First is the corporate form, in which the fund is constituted under an instrument of incorporation, giving it a legal personality distinct from its shareholders. ${ }^{44}$ The second form is the trust structure, ${ }^{45}$ a primarily common law concept whereby the mutual fund is established as a trust and managed by a trustee for the benefit of the investors. ${ }^{46} \mathrm{~A}$ unit trust is constituted under a trust deed. ${ }^{47}$ The fund does not have a separate legal personality, ${ }^{48}$ and the unitholders directly own the deposited property ${ }^{49}$ The terminology in mutual funds varies between states and most countries outside the common law system allow only the corporate form. ${ }^{50}$ Under both forms, investors can redeem their units from the fund directly at any time. ${ }^{51}$

While technical differences exist between the two forms, in the areas relevant to this article, the two forms operate similarly. Mutual funds rely exclusively on external staff and do

\footnotetext{
${ }^{43}$ Sergeeva, 'Collective investment schemes regulations' (2009) 3 Scientific journal NRU ITMO 1-13.

${ }^{44}$ Ibid; Open Ended Investment Company Regulations 2001, reg 2 (1).

${ }^{45}$ Sergeeva, supra $\mathrm{n} 43$. A trust is an equitable obligation binding a person ('trustee') to deal with property over which he has control ('the trust property'), for the benefit of persons ('beneficiaries'). See Hayton et al., Underhill and Hayton: Law Relating to Trusts and Trustees (2010).

${ }^{46}$ See Sergeeva, supra n 43; Giles et al., Managing Collective Investment Funds, 2nd edn (2005) at 27.

${ }^{47}$ McCormack, 'OEICs and trusts: the changing face of English investment law' (2000) 21 Company Law 2 at 3. The funds vest in the name of the trustee, which can be a 'trust corporation', but the trustee's corporate structure is not imputed to the trust itself. See e.g. House of Lords 3rd report 'Directive on Alternative Investment Fund Managers, Volume II: Evidence', The Stationery Office, 10 February 2010 at 308; Brentani, Portfolio Management in Practice (2003) at 10.

${ }^{48}$ McComack, supra $\mathrm{n} 47$ at 3.

${ }^{49}$ See Ball, Hedge Funds: Jurisdictional Comparisons (2011) at 64.

${ }^{50}$ Ibid at 27.

${ }^{51}$ McCormack, supra n 47 at 3.
} 
not have direct employees. ${ }^{52}$ This distinguishes them from normal corporate structures, in which the business directly employs managers, directors and other employees, alongside any external service providers. ${ }^{53}$ There are two primary fiduciary actors in each type of mutual fund. Under the trust fund, these are called the manager and the trustee ${ }^{.54}$ the counterparts in the corporate form are called, respectively, the authorized corporate director (ACD) or board of directors, and the depositary. ${ }^{55}$ For the remainder of this article, we consolidate the technical terms and use 'manager' to refer to both managers and ACD, and 'trustee' to refer to both trustees and depositaries.

The manager makes the investment decisions on behalf of the fund under the direction and supervision of the trustee, who is responsible for safekeeping the fund's assets and overseeing the manager's activities. ${ }^{56}$ Under both forms, the manager and the trustee must be separate corporate bodies, both from the fund and from each other. ${ }^{57}$ Consequently, the fund uses only external service providers. ${ }^{58}$ Both $\mathrm{UK}^{59}$ and $\mathrm{US}^{60}$ law impose fiduciary obligations on

\footnotetext{
${ }^{52}$ See Government Accountability Office, 'Mutual fund fees: additional disclosure could encourage price competition: report to congressional requesters' 5 June 2000 at 25 .

${ }^{53}$ Sjåfjell, Towards a Sustainable European Company Law: A Normative Analysis of the Objectives of EU Law, with the Takeover (2009) at 68-70.

${ }^{54}$ See Review of the Governance Arrangements of United Kingdom Authorised Collective Investment Schemes, the Investment Management Association report, November 2004 at 16.

${ }^{55}$ See Open Ended Investment Company Regulations 2001, reg 34 (4); Alshaleel, supra n 28 at 18.

${ }^{56}$ Collective Investment Schemes Sourcebook 2014, coll 6.6.4; Open Ended Investment Company Regulations 2001, reg 34 (4); Alshaleel, supra n 28 at 18.

${ }^{57}$ Financial Services and Markets Act 2000 s 243 (4), (5)(a), (b) and (7); Open Ended Investment Company Regulations 2001, regs 6, 8. The depositary must be a body corporate incorporated either in the UK or other EEA state and must have its affairs administrated in the country in which it is incorporated, with a place of business in the UK. Ibid.

${ }^{58}$ See Government Accountability Office, 'Mutual fund fees: additional disclosure could encourage price competition: report to congressional requesters' 5 June 2000 at 25.

${ }^{59}$ Collective Investment Schemes Sourcebook 2014, coll 6.6.5 (1), and Open Ended Investment Company Regulations 2001, reg. 35 (2). A fiduciary obligation in this context means a legal relationship of trust and confidence in which the fiduciary is under a duty to act with good faith for the benefit of the principal. Ibid. See also Financial Conduct Authority Sourcebook, 2001 No. 1228.

${ }^{60}$ Investment Company Act of 1940, 15 U.S.C.A $\$ \S 80 a-1-80 a-64$, sec 36 (b); Securities Act of 1933, 15 U.S.C.A. $\S$ 77a, et seq.; Securities Exchange Act of 1934, 17 U.S.C.A. § 78a, et seq.; the Investment Advisers Act of 1940, 15 U.S.C.A. $\S \S 80 b-1-80 b-21$.
} 
mutual fund managers and directors to act in the best interests of the investors, however contractual clauses often limit the manager's liability to the fund to actions or omissions rising to the level of negligence, wilful default or fraud. ${ }^{61}$

\section{Graphic 1: Mutual Fund}

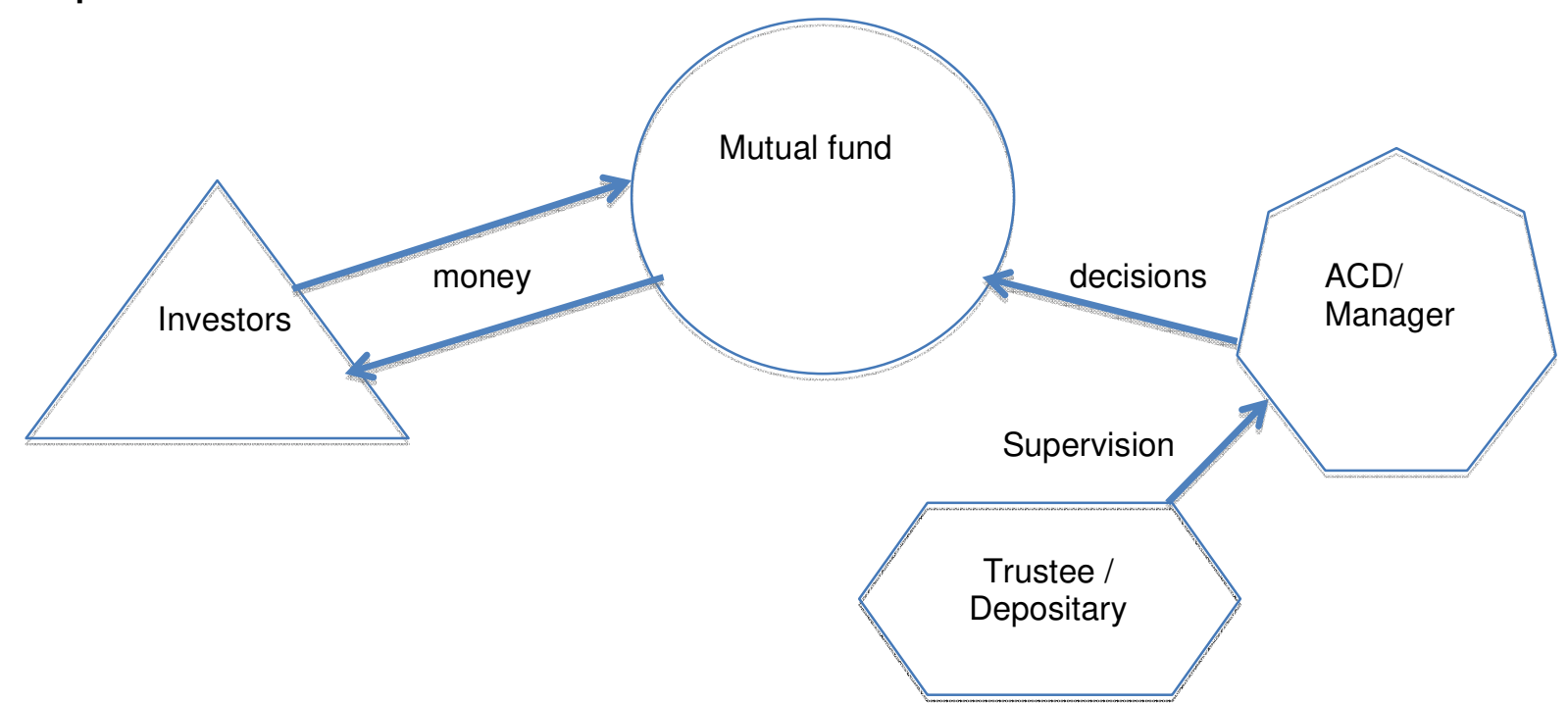

In addition to the managers and trustees, mutual funds might use other service providers.

The service providers allowed and involved vary between jurisdictions, but a fund manager will often delegate administrative tasks, ${ }^{62}$ and may delegate specific functions to an investment adviser who will find opportunities but cannot make decisions on the fund's behalf. ${ }^{63}$

\footnotetext{
${ }^{61}$ Open Ended Investment Company Regulations 2001, reg 62.

${ }^{62}$ Baker et al., supra n 22 at 405.

${ }^{63}$ Shepherds Investments Ltd $v$ Walters [2006] EWHC $836(\mathrm{Ch})$, at para 9.
} 
(ii) The importance of a fund's objectives

Managers must invest the mutual fund's assets according to the fund's objectives, which the investor accepts upon buying shares or units. ${ }^{64}$ Understanding the significance of a fund's objectives is important when it comes to regulating the industry. The investment objectives define the fund's fundamental investment aim, ${ }^{65}$ and investors choose fund types that match their personal investment needs and goals. Some funds aim to increase the value of the basic amount invested (growth funds), while others seek to provide investors with regular income through the payment of dividends (fixed income funds). ${ }^{66}$ The investment objective often indicates the type of assets that constitute the key part of the fund's investment portfolio. ${ }^{67}$ For instance, bond funds are fixed-income funds that mainly buy debt instruments, such as bonds or governments securities, ${ }^{68}$ whereas a money market fund has a short-term objective, usually investing in securities paper that mature more quickly, such as treasury bills and commercial paper. ${ }^{69}$

Investment objectives are usually quite detailed, delineating the risks of the fund, the rights and responsibilities of the trustee, manager and investors, and the criteria that will guide the manager's decisions. ${ }^{70}$ Because investment objectives are defined at the outset and are binding on the manager, the manager has limited flexibility in terms of what it can purchase. ${ }^{71}$ For example, a money market fund's manager cannot buy instruments that mature over a long period because that would breach the fund's short-term objectives. ${ }^{72}$

\footnotetext{
${ }^{64}$ Collective Investment Schemes Sourcebook 2014, coll 4.2.5.

${ }^{65}$ Ibid.

${ }^{66}$ Northcott, The Mutual Funds Book: How to Invest in Mutual Funds \& Earn High Rates of Returns Safely (2009) at 51 .

${ }^{67}$ Ibid.

${ }^{68}$ Mobius, supra $\mathrm{n} 2$ at 21.

${ }^{69}$ Haslem, Portfolio Structures, supra n 20 at 8.

${ }^{70}$ For further information about the regulation requirements regarding the investment objectives, see Collective Investment Schemes Sourcebook 2014, coll 4.2.5.3.

${ }^{71}$ Collective Investment Schemes Sourcebook 2014, coll 6.6.3.

${ }^{72}$ Ibid.
} 


\section{The Unique Issues with Mutual Funds}

There are several distinct elements to mutual funds that set them apart from other types of businesses and that warrant particular attention for the field of business and human rights. First, unlike traditional companies, there are no direct employees of the fund. ${ }^{73}$ As companies are generally judged by and through the actions of their employees, ${ }^{74}$ the purely external nature of mutual fund management can raise questions about the fund's human rights responsibilities. If a fund harms human rights, the fund is responsible for the impacts $;^{75}$ yet there are no employees in the fund and the management sits separate from the fund. A mutual fund manager has a duty to both the fund as well as to its own separate corporate body, and will seek to acquire the highest possible earnings for its corporate body. ${ }^{76}$ Mutual fund managers may be tempted to invest the fund's assets without regard to human rights in order to gain higher returns for their company. While the temptation to prioritize profits over human rights is common across industries, the exclusively external nature of mutual fund management carries the potential for unique conflicts of interest. $^{77}$

To explain the threat, it is helpful to compare mutual funds to traditional parentsubsidiary relationships, in which a single actor may serve both the parent and the subsidiary in different capacities. ${ }^{78}$ A parent company has an ownership interest in the subsidiary and ostensibly suffers from any financial loss experienced by the subsidiary (although sometimes to a

\footnotetext{
${ }^{73}$ See Government Accountability Office, 'Mutual fund fees: additional disclosure could encourage price competition: report to congressional requesters' 5 June 2000 at 25.

${ }^{74}$ See Freedman, Internal Company Investigations and the Employment Relationship (1994) at 141.

${ }^{75}$ See Bogle, Common Sense on Mutual Funds (2010) at 423.

${ }^{76}$ Mobius, supra n 2 at 11; Haslem, Portfolio Structures, supra n 20 at 43.

${ }^{77}$ Haslem, Portfolio Structures, supra n 20 at 43.

${ }^{78}$ See generally Skinner, 'Rethinking Limited Liability of Parent Corporations for Foreign Subsidiaries' Violations of International Human Rights Law’ (2015) 72 Washington and Lee Law Review 1769.
} 
lesser extent than if the parent was directly liable). ${ }^{79}$ Additionally, in limited situations the parent can become liable for the actions of the subsidiary. ${ }^{80}$ With a mutual fund, the manager does not have an ownership interest, does not bear the risk and functions as a fully independent and external actor. ${ }^{81}$ While a manager may separately face criminal responsibility for its own actions, ${ }^{82}$ generally managers financially benefit from the fund doing well while imputing liability to an entity without assuming attendant financial risks. ${ }^{83}$ The parent-subsidiary role limits risks for the parent, but the manager-fund relationship leaves the manager without significant risks for the management company.

A second significant feature is in the responsibility of mutual funds to buy out shares from investors at any time. ${ }^{84}$ Stocks in traditional companies need to be sold, and the price can fluctuate substantially based on the market. ${ }^{85}$ Shareholders in an individual company have an interest in monitoring human rights practices because bad practices can result in civil claims or public relations problems, affecting the stock price. ${ }^{86}$ The diversification of a mutual fund, however, limits the impact of any one company's price fluctuation on the fund's value. ${ }^{87}$ Redemption values are based on the totality of assets in the fund at the time the investor exchanges her shares. ${ }^{88}$ The limited impact of any one company on a fund's value and the ability

\footnotetext{
${ }^{79}$ Ibid at $1775,1777$.

${ }^{80}$ Chandler $v$ Cape, plc, [2012] EWCA CIV 525.

${ }^{81}$ See Mobius, supra $\mathrm{n} 2$ at 11 . The manager may lose investors or clients, but this is an indirect harm.

${ }^{82}$ Collective Investment Schemes Sourcebook 2014, coll 6.6.5(1).

${ }^{83}$ See Haslem, Portfolio Structures, supra n 20 at 57.

${ }^{84}$ Collective Investment Schemes Sourcebook 2014, coll 6.2.16 (6).

${ }^{85}$ See generally Roiter, 'An Apology for Mutual Funds: Delivering Fiduciary Services to Middle and Working Class Investors' (2004) 23 Annual Review of Banking \& Financial Law 851-862.

${ }^{86}$ Baumann-Pauly and Nolan, Business and Human Rights: From Principles to Practice (2016) at 214.

${ }^{87}$ Jones, Mutual Funds: Your Money, Your Choice: Take Control Now and Build Wealth Wisely (2003) at 47.

${ }^{88}$ See ibid at 19.
} 
to easily redeem shares from the fund means investors are unlikely to experience significant losses because of the fund's human rights impacts. ${ }^{89}$

The purpose and structure of mutual funds provides broad access to professional investment skills that would otherwise be unavailable to unsophisticated investors. The external management distinguishes the fund from other forms of business. The unsophisticated nature of the majority of mutual fund investors coupled with the fund's liquidity means individual investors are unlikely to have an interest in the long-term structural decisions of the fund. ${ }^{90}$ Collectively, these issues raise questions about how mutual funds can implement their human rights responsibilities.

\section{The Demands of Business and Human Rights}

With the nature and structure of mutual funds established, it is important to consider the human rights responsibilities of businesses, as well as how these responsibilities have been interpreted and applied to the financial services industry. The UNGP set a standard for all business, regardless of type and size, and carry an expectation that mutual funds, like all other businesses, will respect human rights. ${ }^{91}$ This section considers the challenges of applying the UNGP to the mutual fund industry.

\section{A. Business and State Responsibilities under the UN Guiding Principles}

As noted above, the UNGP assert that states are to protect human rights, businesses should respect human rights and both states and businesses should offer adequate remedies when

\footnotetext{
${ }^{89}$ See Haslem, Risk and Performance, supra n 5 at 38.

${ }^{90}$ See ibid.

${ }^{91}$ See UNGP, supra n 12 at General Principles.
} 
impacts do occur. ${ }^{92}$ On their own, the UNGP are non-binding but the articulation of state responsibility is reflective of existing treaty and customary obligations. ${ }^{93}$ The Guiding Principles intentionally eschewed calls for direct international legal responsibility for businesses, ${ }^{94}$ and the expectations on businesses are expressed only as 'responsibilities' that stem from the 'social license to operate'. ${ }^{95}$ The expectation, however, is that the business responsibility to respect should become the minimum legal standard through domestic implementation. ${ }^{96}$ This section considers the state duty to protect and the business responsibility to respect human rights, as outlined in the UNGP.

\section{(i) The state duty to protect}

International and regional human rights courts and treaty bodies have long recognized that each human right entails three distinct obligations: respect, protect and fulfil. ${ }^{97}$ This tripartite typology does not explicitly appear in the text of human rights treaties, but is 'seen as a particular means of expressing and conceiving of existing human rights obligations' ${ }^{98}$ The obligation to protect requires states to take action to prevent third parties from interfering with the realization of human rights. ${ }^{99}$ As the United Nations Committee on Economic, Social and Cultural Rights

\footnotetext{
${ }^{92}$ UNGP, supra n 12.

${ }^{93}$ See Buhmann, 'Navigating from 'Train Wreck' to being 'Welcomed': Negotiation Strategies and Argumentative Patterns in the Development of the UN Framework' in Deva and Bilchitz, supra n 14 at 29, 52; de Schutter, 'Towards a New Treaty on Business and Human Rights' (2015) 1 Business and Human Rights Journal 41 at 44; Wettstein, 'The Duty to Protect: Corporate Complicity, Political Responsibility, and Human Rights Advocacy' (2010) 96 Journal of Business Ethics 33 at 34-35, 41.

${ }^{94}$ UNGP, supra n 12 at Principles 11-24, 29-31, and accompanying commentary. See also Martin and Bravo, Introduction, supra $\mathrm{n} 15$ at 5.

${ }^{95}$ Ruggie, 'Protect, Respect and Remedy: A Framework for Business and Human Rights' U.N. Doc. A/HRC/8/5 (7 April 2008) at para 54.

${ }^{96}$ See UNGP, supra n 12 at Principle 1 and Commentary; Office of the High Commissioner for Human Rights, 'The Corporate Responsibility to Respect Human Rights: An Interpretive Guide' U.N. Doc. HR/PUB/12/02 (2012) at 1.

${ }^{97}$ See Mégret, 'Nature of Obligations,' in Moeckli, Shah and Sivakumaran (eds), International Human Rights Law 2nd edn (2014), 96 at 101-202. On the European and Inter-American adaptations of the tripartite approach, see Ahmed and de Jesús Butler, 'The European Union and Human Rights: An International Law Perspective' (2006) 17 European Journal of International Law 771 at 797-800.

${ }^{98}$ Ahmed and de Jesús Butler, supra n 97 at 800.

${ }^{99}$ Megret, supra n 97 at 101-102.
} 
(CESCR) has explained, the duty to protect requires 'establishing appropriate laws and regulations, together with monitoring, investigation and accountability procedures to set and enforce standards for the performance of corporations'. ${ }^{100}$ While the state is not responsible every time a business interferes with the realization of human rights, a business's impact on human rights 'can lead to international responsibility of the State' if the state's fails to exercise 'due diligence to prevent the violation or to respond to it'. ${ }^{101}$ Accordingly states must therefore take steps to regulate known or likely business impacts on human rights, to supervise and inspect businesses and to respond with due care to allegations of new impacts. ${ }^{102}$ Where a business's actions are lawful but, according to the UNGP, irresponsible, the state is expected to regulate proscriptively and to ensure remedies are available if damages occur. ${ }^{103}$ A failure to regulate with due diligence and/or ensure remedies can result in the actions of the business being imputed to the state, leading to a violation of the state's obligations. ${ }^{104}$

(ii) The business responsibility to respect

The responsibility to respect human rights means that businesses should refrain from interfering in the realization of human rights. ${ }^{105}$ The responsibility exists regardless of the entity's 'size, sector, operational context, ownership and structure', ${ }^{106}$ and functions independently from the state's duty to protect so that even where the state fails to adequately regulate, the business must

\footnotetext{
${ }^{100}$ Committee on Economic, Social, and Cultural Rights (CESCR), Statement on the Obligations of States parties regarding the corporate sector and economic, social and cultural rights, E/C.12/2011/3, Annex VI(A), adopted 20 May 2011 at para 5.

${ }^{101}$ Velasquez Rodrguez v Honduras (Judgment), IACthR Series C No 4 (29 July 1988) at para 172. For similar conclusions by other bodies, see e.g. Human Rights Committee, General Comment 27, U.N. Doc. CCPR/C/21/Rev.1/Add.9 (1999) at para 7; CESCR, General Comment No. 14, U.N. Doc. E/C.12/2000/4 (2000) at para 51; Lopez Ostra v Spain, Application no. 16798/90 (1994) at paras 56-58; Social and Economic Rights Actions Center v Nigeria, Communication 155/96, 15th ACHPR AAR Annex V (2000-2001) at para 8.

${ }^{102}$ See UNGP, supra n 12 at Principles 1-3 and accompanying commentary. See also de Schutter, supra n 93 at 44.

${ }^{103}$ See UNGP, supra n 12 at Principles 1-3, 25, and accompany commentary.

${ }^{104}$ See supra $\mathrm{n} 115$.

${ }^{105}$ UNGP, supra n 12 at Principles 11-21 and accompanying commentary.

${ }^{106}$ Ibid at Principle 14.
} 
meet its responsibility. ${ }^{107}$ Similarly, a business's responsibility is not excused simply because others in the same industry fail to meet their responsibilities. ${ }^{108}$ According to the UNGP, businesses are expected 'to prevent or mitigate adverse human rights impacts that are directly linked to their operations, products or services' because of 'business relationships, even if they have not contributed to those impacts'. ${ }^{109}$ Relevant 'business relationships' include associations with any 'entity directly linked to its business operations, products or services' ${ }^{110}$ It is the existence of a link between an impact and the business's activities, rather than the business's level of contribution to a human rights violation, that triggers its responsibility to respect. ${ }^{111}$

The UNGP suggest that businesses first adopt human rights specific policies and practices at the 'senior level of the businesses'. ${ }^{112}$ A clear 'policy commitment', informed by internal and external expertise, should detail 'the enterprise's human rights expectations of personnel, business partners and other parties directly linked to its operations, products or services'. ${ }^{113}$ The policy should be incorporated into 'operational policies and procedures' and communicated to relevant personnel and stakeholders. ${ }^{114}$ Businesses are then to conduct due diligence in order to identify salient human rights issues, mitigate their impact and remedy any impacts that cannot be avoided. ${ }^{115}$

\footnotetext{
${ }^{107}$ Ibid at Principle 11, Commentary; Karp, Responsibility for Human Rights: Transnational Corporations in Imperfect States (2014) at 152.

${ }^{108}$ See UNGP, supra n 12 at Principles 11, 13-14 and commentary.

${ }^{109}$ See UNGP, supra n 12 at Principle 13(b).

${ }^{110}$ Ibid at Principle 13, commentary.

${ }^{111}$ Ibid at Principle 13(b).

${ }^{112}$ Ibid at Principle 15 and accompanying Commentary.

${ }^{113}$ Ibid at Principles 15-16 and accompanying Commentary.

${ }^{114}$ Ibid.

${ }^{115}$ Ibid at Principles 18-19. See also Footer, 'Human Rights Due Diligence and the Responsible Supply of Minerals from Conflict-Affected Areas: Towards a Normative Framework?' in Letnar Černič and Van Ho, supra n 39, 179 at 184-185.
} 
Due diligence requires businesses assess both actual and potential human rights impacts, respond to those impacts and monitor developments on an ongoing basis. ${ }^{116}$ Internal and external human rights experts and relevant stakeholders should be consulted. ${ }^{117}$ Businesses are to consider those human rights contained in the International Bill of Human Rights ${ }^{118}$ and the ILO Declaration on Fundamental Principles and Rights at Work, but may choose to concentrate on the 'most significant' impacts caused by their operations, but should include in their assessment impacts that are 'due to ... clients' operating context'. ${ }^{119}$ Results of the due diligence process should influence the business's decision-making processes, leading to the mitigation and remediation of impacts. ${ }^{120}$

While the standard for the responsibility to respect is universal, how a business is expected to respond may be influenced by factors such as '[w]hether the business enterprise causes or contributes to an adverse impact, or whether it is involved solely because the impact is directly linked to ... a business relationship' and '[t]he extent of its leverage in addressing the adverse impact'. ${ }^{121}$ Other factors enumerated by the UNGP include 'how crucial the relationship is ... the severity of the abuse, and whether terminating the relationship ... would have adverse human rights consequences'. ${ }^{122}$ Where a company can refrain from engaging in a harmful activity, the expectation is that it will do so. ${ }^{123}$ Where it causes or contributes to a harm, it is

\footnotetext{
${ }^{116}$ Fasterling and Demuijnck, 'Human Rights in the Void? Due Diligence in the UN Guiding Principles on Business and Human Rights' (2013) 116 Journal of Business Ethics 799, at 801.

${ }^{117}$ UNGP, supra n 12 at Principle 18 and accompanying commentary.

${ }^{118}$ Ibid at Principle 12. The International Bill of Human Rights refers to the Universal Declaration of Human Rights, the International Covenant on Civil and Political Rights, and the International Covenant on Economic, Social and Cultural Rights.

${ }^{119}$ Ibid at Principle 17, commentary.

${ }^{120}$ Ibid at Principle 20.

${ }^{121}$ Ibid at Principle 19.

${ }^{122}$ Ibid at Principle 19, Commentary.

${ }^{123}$ Ibid.
} 
responsible for attempting to mitigate the harm and for providing remedies when harms occur. ${ }^{124}$ Even where a business does not cause or contribute to the harm, the business is expected to exercise leverage to limit or mitigate the human rights impacts by those entities with which it has a business relationship. ${ }^{125}$ This approach requires a business to be actively engaged in reducing its human rights impacts. Responses should be tracked in order to determine the chosen path's effectiveness and the results communicated to stakeholders and interested parties. ${ }^{126}$ The process is intended to be cyclical so that ongoing due diligence efforts are enhanced by previous results and lessons learned. ${ }^{127}$

Implementation of the UNGP has been slow. ${ }^{128}$ While an increasing number of businesses are adopting and reporting on human rights policies, many companies still fail to recognize their human rights responsibilities while others may recognize their responsibility but fail to report on their practices in a substantial way. ${ }^{129}$ Additionally, some corporate reporting on human rights is rather shallow, either lacking significant detail or intentionally focusing on less consequential human rights issues and obscuring significant harms. ${ }^{130}$ This currently makes it difficult for financial actors to evaluate every business in which they would invest. We suggest practical solutions for this problem in Part 4.B., below.

\footnotetext{
124 Ibid.

${ }^{125}$ Ibid

${ }^{126}$ Ibid at Principles 20, 21.

${ }^{127}$ Ibid at Principle 20.

${ }^{128}$ Business \& Human Rights Resource Centre, 'Development for All, or a Privileged Few? Human Rights in Southeast Asia' (2015) at 4, available at: businesshumanrights.org/sites/default/files/Southeast $\% 20$ Asia $\% 20$ Briefing $\% 2016 \% 20$ April\%202015.pdf [last accessed 5 December 2017]; Naki B. Mendoza, 'Will Corporate Human Rights Reports Become the Norm?' Devex Impact (2015), available at www.devex.com/news/will-corporate-human-rights-reports-become-the-norm-86611 [last accessed 5 December 2017].

${ }^{129}$ Weber, 'Research Note. The Extractive Industry and the UN Guiding Principles on Business and Human Rights' Principles for Responsible Investment (2015) at 7.

${ }^{130}$ See ibid at 7 .
} 


\section{B. Applying the UNGP to Financial Entities}

\section{(i) The business responsibility to respect}

Applying the UNGP to financial actors has proven difficult at times because 'money is never the direct means by which gross human rights violations are perpetrated' ${ }^{131}$ However, this does not absolve financial entities from responsibility under the UNGP, even when their conduct does not legally rise to the level of financial complicity. ${ }^{132}$ Complicity under international criminal law requires an action that has a 'substantial effect' on the commission of the violation. ${ }^{133}$ Proving complicity for human rights violations based on a financial transaction has been difficult because the transaction is often 'removed from human rights violations carried out by their recipients' ${ }^{134}$

The UNGP uses a broader, and perhaps less technical approach, recognizing both legal and non-legal forms of complicity. ${ }^{135}$ Guiding Principle 13 explains that the responsibility to respect 'requires' businesses '[a]void causing or contributing to adverse human rights impacts through their own activity'(emphasis added). ${ }^{136}$ The 'contributing to' standard includes a broader understanding of complicity than that employed by international criminal law. ${ }^{137}$ John Ruggie, author of the UNGP, concluded that '[c]omplicity in the business and human rights context refers to the indirect involvement of companies in human rights abuses', and can refer to

\footnotetext{
${ }^{131}$ Michalowski, supra $\mathrm{n} 6$ at 452.

${ }^{132}$ For extensive discussions on the issue of complicity, see Michalowski, supra n 6; Michalowski, 'The Mens Rea Standard for corporate Aiding and Abetting Liability - Conclusions from International Criminal Law' (2014) 18 UCLA Journal of International Law and Foreign Affairs 237; Wettstein, supra n 93 at 34-35; Bohoslavsky, Financial Complicity, supra n 33.

${ }^{133}$ South African Apartheid Litigation, supra n 8 at 269; see also Ruggie, 'Clarifying the Concepts of "Sphere of influence" and "Complicity"' U.N. Doc. A/HRC/8/16 (15 May 2008) at para 30.

${ }^{134}$ Michalowski, supra n 6 at 453; see also South African Apartheid Litigation, supra n 8.

${ }^{135}$ UNGP, supra n 12 at Principle 17, Commentary; see also Mares, 'A Gap in the Corporate Responsibility to Respect Human Rights' (2010) 36 Monash University Law Review 33 at 44 (questioning the appropriateness of this approach).

${ }^{136}$ UNGP, supra n 12 at Principle 13.

${ }^{137}$ Ibid at Principle 17, Commentary.
} 
situations in which 'a company knowingly contributed to another's abuse of human rights'. ${ }^{138}$ '[I]ndirect involvement' refers to instances when 'the company itself does not actually carry out the abuse'. ${ }^{139}$ The effect of the contribution appears less relevant under the UNGP when compared to international criminal law. ${ }^{140}$ The UNGP standard appears to be in addition to, and triggered at a lower threshold than, any criminal complicity that uses the 'substantial effect' test. If a business benefits from abuse, or financially supports an abusive regime, it appears to have triggered this lower threshold, even if the indirect nature of the support means a criminal or civil case for complicity cannot be sustained. ${ }^{141}$

The difference between the two approaches to 'complicity' appears to have caused some confusion among financial actors. The Thun Group of Banks, an informal network of ten banks, has inaccurately asserted that 'a bank would generally not be considered to be causing or contributing to adverse human rights impacts arising from its clients' operations because the impact is not occurring as part of the bank's own activities'. ${ }^{142}$ While recognizing that banks are expected to conduct due diligence on the impact of their financial transactions, the Thun Group argues that bank's conduct 'does not shift responsibility for the impact from the client .... to the bank. ${ }^{143}$ The banks posit that their relationships with clients do not give rise to the bank's

\footnotetext{
${ }^{138}$ Ruggie, Clarifying the Concepts, supra n 133 at para 30.

${ }^{139}$ Ibid at para 30.

${ }^{140}$ See Mares, supra n 135.

${ }^{141}$ See Ruggie, 'Comments on the Thun Group of Banks' Discussion Paper on the Implications of UN Guiding Principles $13 \& 17$ In a Corporate and Investment Banking Context', 21 February 2017, at 2-3, available at: business-humanrights.org/sites/default/files/documents/Thun\%20Final.pdf [last accessed 5 December 2017]; Addo, Letter to the Thun Group, 23 February 2017, at 3-4, available at: www.ohchr.org/Documents/Issues/TransCorporations/WG_BHR_letter_Thun_Group.pdf [last accessed 5 December 2017].

${ }^{142}$ Thun Group of Banks 'Discussion Paper on the Implications of UN Guiding Principles 13 \& 17 in a Corporate and Investment Context', 25 January 2017, at 6, available at: business-

humanrights.org/sites/default/files/documents/2017_01_Thun\%20Group\%20discussion\%20paper.pdf [last accessed 5 December 2017].

${ }^{143}$ Ibid., at 3 (internal citations omitted).
} 
responsibility to respect human rights. ${ }^{144}$ They suggest banks can encourage better client behaviour but do not incur responsibility for what the clients do with the bank's financing. ${ }^{145}$ This position mirrors earlier understandings of 'corporate social responsibility,' or 'ethical' initiatives, in which businesses could undertake positive actions if they chose to but did not have any responsibility for their negative human rights impacts unless they fell afoul of local laws. ${ }^{146}$

Ruggie, the UN Working Group on business and human rights, scholars and civil society have rightly rebuked the Thun Group for its approach. ${ }^{147}$ Ruggie responded by explaining that the 'critical distinction' is not who undertakes the activities - the bank or a client - but whether the harm is one the bank is 'contributing to' or is one committed by a third party to which the bank is "'directly linked" through their business relationships even without' the bank 'having caused or contributed to the harm. ${ }^{148}$ In the former case the bank's responsibility to respect is triggered, even though it does not directly undertake the actions causing the harm. ${ }^{149}$ Examples of this include, according to Ruggie, where a bank grants 'a general corporate loan to a private prison company that is alleged to engage in severe human rights abuses. ${ }^{150}$ In this case, the bank should undertake due diligence and impose 'strict conditions' if it grants the loan. ${ }^{151}$ The UN Working Group similarly recognized that a bank can cause or contribute to an impact, for

\footnotetext{
${ }^{144}$ See Thun Group of Banks, 'UN Guiding Principles on Business and Human Rights: Discussion Paper for Banks on Implications of Principles 16-21', October 2013, at 5, available at: business-

humanrights.org/sites/default/files/media/documents/thun-group-discussion-paper-final-2-oct-2013.pdf [last accessed 5 December 2017].

145 See ibid.

${ }^{146}$ See Ramasastry, 'Corporate Social Responsibility Versus Business and Human Rights: Bridging the Gap Between Responsibility and Accountability' 14 Journal of Human Rights 237 (2015) at 237-239.

${ }^{147}$ See Ruggie, Comments, supra n 169; Addo, supra n 169; 'Significant Concerns Regarding Thun Group Discussion Paper', Joint Letter from Civil Society, 14 February 2017, available at: www.businesshumanrights.org/sites/default/files/documents/170214_Open_letter_to_Thun_Group.pdf [last accessed 5 December 2017]; Kinley, 'Artful Dodgers: Banks and their Human Rights Responsibilities' Sydney Law School Research Paper No. 17/17, posted 2 Mar 2017, available at: papers.ssrn.com/sol3/papers.cfm?abstract_id=2926215 [last accessed 5 December 2017].

${ }^{148}$ Ruggie, Comments, supra n 141 at 2.

${ }^{149}$ Ibid.

${ }^{150}$ Ibid.

${ }^{151}$ Ibid.
} 
instance if it 'provides a loan for an infrastructure project that leads to widespread displacement of local communities' unless the loan requires adequate safeguards or mitigation techniques. ${ }^{152}$ Where the bank has not failed to meet its responsibility to respect, but the bank can still be expected to use its leverage to influence a client's conduct. ${ }^{153}$

While the understandings presented by Ruggie and the Working Group are not binding, they are clearly authoritative interpretations given that Ruggie drafted the UNGP and the Working Group has been entrusted by states to, inter alia, 'provide advice and recommendations regarding the development of domestic legislation and policies relating to business and human rights'. ${ }^{154}$ Moreover, they align with the plain reading of the UNGP, which recognizes that the responsibility for human rights attaches to a wider range of actions than those that immediately cause a negative impact. ${ }^{155}$ The examples provided by Ruggie and the Working Group demonstrate that financial actors can contribute to a harm simply by providing necessary financing, even if the financing is general in nature. ${ }^{156}$ In such cases, the financial actor has a responsibility o mitigate its impacts and to provide remedies. ${ }^{157}$

Like a bank, a mutual fund could contribute to a human rights violation by financing an oppressive regime or a company involved in human rights abuses. ${ }^{158}$ This would trigger the lower threshold of the UNGP responsibility to respect while not necessarily rising to the level of complicity in international criminal law. In the context of mutual funds, mitigating an impact

\footnotetext{
${ }^{152}$ Addo, supra n 141 at 2.

${ }^{153}$ Ibid.

${ }^{154}$ HRC Res 17/4, 6 July 2011, A/HRC/RES/17/4, at para 6(c).

${ }^{155}$ See UNGP, supra n 12 at Principle 13.

${ }^{156}$ See Ruggie, Comments, supra n 141 at 2-3.

${ }^{157}$ UNGP, supra n 12 at Principles 13, 19, and accompanying commentary. The Thun Group was also criticized for its denial of banks' remediation responsibilities. Compare Thun Group, 2017 Discussion Paper, supra n 142 at 15 ; Addo, supra n 141 at 3-4.

${ }^{158}$ See Joint Committee on Human Rights, 'Any of Our Business?: Human Rights and the UK Private Sector, First Report of Session;, (2009), at para 61-62, available at: http://www.publications.parliament.uk/pa/jt200910/jtselect/jtrights/5/5i.pdf [last accessed 5 December 2017].
} 
would mean selling an investment and moving the assets to different investments. While the UNGP recognize that businesses may need to continue 'crucial' relationships despite human rights harms, the understanding of a 'crucial' relationship is narrow, referring to circumstances where another entity 'provides a product or service that is essential' for the business 'for which no reasonable alternative source exists'. ${ }^{159}$ As noted above, few corporations have human rights commitments or due diligence processes, ${ }^{160}$ making it difficult for mutual funds to invest only in human rights compliant companies or states. Given the purpose of mutual funds, however, there will often be equal or relatively equal enterprises to invest in. In such circumstances, the UNGP would seemingly require mutual fund managers to prioritize companies and states that inculcate good human rights standards over investments with poor human rights compliance and to increasingly move assets to companies and states that respond well to human rights concerns. Fund managers should justify investments in non-compliant businesses and states by explaining to stakeholders and shareholders the reasons for the purchase and the lack of legitimate and available alternatives. ${ }^{161}$

\section{(ii) The limitations of human rights initiatives for financial actors}

Effectively changing the treatment of human rights within the financial markets has proven difficult. ${ }^{162}$ Significant for this piece, Mary Dowell-Jones has found that there is a lack of clear and appropriate guidance addressing issues of financial actors generally and the needs of specific products and actors. ${ }^{163}$ Most soft-law and advisory instruments addressing the human rights responsibilities of financial actors consider lending policies and project financing activities in

\footnotetext{
${ }^{159}$ UNGP, supra n 12 at Principle 19, Commentary.

${ }^{160}$ Supra n 141-42.

${ }^{161}$ See ibid at Guiding Principle 19 and accompanying commentary.

${ }^{162}$ Dowell-Jones, supra n 11 at 426.

${ }^{163}$ Ibid at 426, 427, 440-441.
} 
which the financial entity can exert clear control or influence over corporate conduct. ${ }^{164}$ Where other market actors have been addressed, it has been often through 'ethical' initiatives, some of which have been widely embraced but have translated into limited change in practice. ${ }^{165}$ Of these 'social responsibility' initiatives, ${ }^{166}$ the UN Principles for Responsible Investment ('UNPRI'), a voluntary and industry-led initiative, is the most substantial effort aimed at institutional investors, like mutual fund managers. ${ }^{167}$ It is necessary to examine why these initiatives are insufficient for addressing business and human rights standards in the context of mutual funds.

First, banks and financial institutions can require human rights policies and due diligence as a condition for loans or project financing. ${ }^{168}$ In doing so, banks and financial institutions can distinguish between companies within a corporate group's operations or between projects a single business undertakes. ${ }^{169}$ Imagine Company A is the parent company to Company B and Company C. When granting a loan or project financing, a bank can distinguish between operations conducted by Company B and Company C. Similarly, if Company C has traditionally operated only in one state, like Nigeria, and seeks to develop a new project in a nearby state, like Benin, a bank can distinguish between the two sets of operations, making loans for the Benin operations contingent on human rights standards applicable to that project regardless of Company C's record in Nigeria. In these circumstances, the bank or financial institution can manage its direct human rights impact. Mutual fund investments, on the other hand, generally do not distinguish between companies within a corporate group or between operations within a

\footnotetext{
${ }^{164}$ See 'Equator Principles III', 2013, available at: www.equator-principles.com [last accessed 5 December 2017]; van Genugten, The World Bank Group, the IMF, and Human Rights: A Contextualized Way Forward (2015). See also Rothe, supra n 11; UNPRI, 'About the PRI' available at: www.unpri.org/about [last accessed 5 December 2017]; Meyersfeld and Kinley, supra n 9.

${ }_{165}$ Dowell-Jones, supra $\mathrm{n} 11$ at 424-426.

${ }^{166}$ See supra $\mathrm{n} 146$ and accompanying text.

${ }^{167}$ See UNPRI, About PRI, supra n 164; Weber, supra n 129 at 9.

${ }^{168}$ See Meyersfeld and Kinley, supra n 9 at 196.

${ }^{169}$ Ibid. See also Thun Group, 2017 Discussion Paper, supra n 142 at 9.
} 
single business. Shares are usually publicly traded only for a corporate group's parent company rather than for each entity within the group. ${ }^{170}$ This significant difference makes the guidance developed for bank loans and project financing generally inappropriate for fund managers.

The UNPRI attempt to help investors play an active role in supporting responsible corporate conduct. ${ }^{171}$ UNPRI investors are encouraged to work together to pressure companies to adopt social policies, ${ }^{172}$ and agree to 'incorporate' environmental, social and governance issues 'into investment analysis and decision-making processes' ${ }^{173}$ Like the Thun Group's approach, however, the UNPRI views an institutional investor's role as encouraging others to comply with human rights rather than of directly managing its own human rights impact. As a result, the UNPRI's approach to 'laggard' companies - those that have failed to adopt a human rights commitment even on paper - is to ask signatories to 'request the company publishes a human rights commitment'. ${ }^{174}$ Investors are not required or expected to refrain from investing even when there are serious human rights impacts. ${ }^{175}$ This is a lower threshold than what is required by the UNGP.

For the UNGP, the responsibility to respect requires action beyond just consideration of human rights or advocacy for better commitments by others. ${ }^{176}$ Where alternatives exist, the UNGP seemingly expect managers to seek out and prioritize those alternatives as a means of mitigating the fund's human rights impacts. Investments can be moved with limited difficulty,

\footnotetext{
${ }^{170}$ See Ting, The Taxation of Corporate Groups Under Consolidation: An International Comparison (2013) at 229.

${ }^{171}$ Weber, supra n 129 at 9.

172 Ibid at 4.

${ }^{173}$ See UNPRI, 'The Six Principles', available at: www.unpri.org/about/the-six-principles [last accessed 4 May 2017]; see also Rinaldi, et al., 'The Role of Stakeholder Engagement and Dialogue within the Sustainability Accounting and Reporting Process' in Bebbington, et al., Sustainability Accounting and Accountability, 2nd edn (2007) at 92.

${ }^{174}$ UNPRI, Human Rights and the Extractive Industry: Why Engage, Who to Engage, How to Engage, (2015), at 9, available at: [last accessed 31 August 2016].

${ }^{175}$ See UNPRI, 'The Six Principles,' supra n 173.

${ }^{176}$ Compare ibid; UNGP, supra n 12 at Principles 13, 17, and accompanying commentary.
} 
suggesting the relationship between a fund and its investments will never be a 'crucial' relationship for the fund. Under the UNGP, the fungibility of assets means human rights should become a prerequisite for a mutual fund's investment, rather than one of many considerations. The lack of adequate initiatives for mutual funds makes it necessary to revisit briefly the state's responsibility to regulate the industry for the protection of human rights.

\section{The State's Responsibility}

The duty to protect requires states to adopt general regulations appropriate to all industries as well as specific regulations for individual industries where necessary. ${ }^{177}$ Traditionally, the obligation to protect is assumed to attach territorially, with states responsible for regulating the impacts that occur on their own territory. ${ }^{178}$ Mutual funds are generally created and managed within one state (the 'home state') and primarily purchase shares on the markets of that state. ${ }^{179}$ Their human rights impacts, however, will often occur on the territory of a different state (effectively the 'host state' ${ }^{180}$ ) through the acts of a business or a state in which the fund invests. This raises an important question about which state bears the duty to protect, the home or the host state. While international law provides several jurisdictional bases, the most widely accepted are territorial, meaning the conduct occurs within the territory of the state, and active personality, meaning the person committing the action is a national of the state. ${ }^{181}$ Other forms of jurisdiction are either functionally limited, like universal jurisdiction, or are disputed, such as the

\footnotetext{
${ }^{177}$ UNGP, supra n 12 at Principles 1-2 and accompanying commentary.

${ }^{178}$ See e.g. Bernaz, 'Enhancing Corporate Accountability for Human Rights Violations: Is Extraterritoriality the Magic Pill?' (2013) 117 Journal of Business Ethics 493 at 503-504.

${ }^{179}$ See Turner, International Funds: A Practical Guide to their Establishment and Operation (2004) at 177. There are exceptions to this. See Madura, Financial Institutions and Markets (2008) at 646; Alshaleel, supra n 28 at14, 15.

${ }^{180}$ See Madura, supra n 180 at 646.

${ }^{181}$ See Crawford, Brownlie's Principles of Public International Law, 8th edn. (2012) at 457-460.
} 
protective and passive personality principles. ${ }^{182}$ Since both the operations and nationality of the fund belong with the home state, the host state may not have jurisdiction under international law to regulate the fund. If the home state is the only one capable of regulating the fund's activities, does it bear the duty to protect, even though the impacts are felt abroad?

The debate over home states' human rights responsibilities has been pivotal in the field of business and human rights. ${ }^{183}$ International law has long recognized that while territorial jurisdiction is the standard, active personality jurisdiction gives states the authority to regulate the actions of their citizens abroad through regulatory measures and criminal sanctions. ${ }^{184}$ Does this right ever become a duty? For several human rights treaty bodies, responsible for overseeing state compliance with UN human rights treaties, the answer is yes. ${ }^{185} \mathrm{CESCR}$ has issued General Comments, ${ }^{186}$ a public statement ${ }^{187}$ and Concluding Observations ${ }^{188}$ all asserting that there is a duty to regulate and redress corporate citizens' human rights impacts even when those impacts occur abroad. ${ }^{189}$ This position has been endorsed by the Human Rights Committee, the

\footnotetext{
${ }^{182}$ See ibid at $461-464$.

${ }^{183}$ de Schutter, supra n 93 at 44; Augenstein and Kinley, supra n 14 at 273. See also generally Buhmann, 'Defying Territorial Limitations: Regulating Business Conduct Extraterritorially through Establishing Obligations in EU Law and National Law' in Letnar Černič and Van Ho, supra n 39, 281 at 281-282.

${ }^{184}$ See e.g. The Case of the S.S. “Lotus,” Permanent Court of International Justice, Series A-No. 10, Dissenting Opinion of Judge Moore at 92-93 (1927); Sarkar, 'The Proper Law of Crime in International Law' (1962) 11 International and Comparative Law Quarterly 446 at 451 . See also Bernaz, supra n 186 at 495.

${ }^{185}$ See e.g. CESCR, General Comment 14, supra n 101 at para 39; Human Rights Committee, Concluding Observations on the Sixth Periodic Report of Germany, 12 November 2012, CCPR/C/DEU/CO/6/2 at para 16; Committee on the Rights of the Child, General Comment No. 16 (2013) on State obligations regarding the Impact of the Business Sector on Children's Rights, 17 April 2013, CRC/C/GC/16, at 6-7; Committee on the Elimination of Racial Discrimination, Concluding Observations on Canada, 25 May 2007, CERD/C/CAN/CO/18 at para 17. See also generally, Gerber, et al., 'General Comment 16 on State Obligations Regarding the Impact of the Business Sector on Children's Rights: What is its Standing, Meaning and Effect?' (2013) 14 Melbourne Journal of International Law 93.

${ }^{186}$ CESCR, General Comment No. 14, supra n 101; CESCR, General Comment No. 15: The Right to Water (Arts. 11 and 12) (20 January 2003), at para 33; CESCR, General Comment No. 19: The Right to Social Security (art. 9), 4 February 2008, at para 53.

${ }^{187}$ CESCR, Statement, supra n 101 at para 5.

${ }^{188}$ See e.g. CESCR, Concluding Observations on the Second Periodic Report of China, including Hong Kong, Macao, and China, E/C.12/CHN/CO/2 (13 June 2014) at para 13.

${ }^{189}$ See Bernaz, supra n 179 at 504-505.
} 
Committee on the Rights of the Child, and the Committee on the Elimination of Racial Discrimination. $^{190}$

The mandatory use of active personality jurisdiction comes with concerns about the potential for neocolonialist control by developed states who could undermine the sovereign right of host states to determine and set policy in their own best interests. ${ }^{191}$ Some scholars also worry that if the duty to protect is transferred to home states, host states could in practice rely on that to avoid meeting their own obligations, undermining the protection of human rights. ${ }^{192}$ Claims of home state responsibility normally raise these complex considerations about the relationship between states, but in the context of mutual funds such concerns are largely misplaced. States are generally recognized as having wide latitude to regulate activities within their state even when that activity has extraterritorial impact. ${ }^{193}$ Given a mutual fund's nationality and the locus of its activity are usually limited to the home state, the only practical approach to the duty to protect is to find it attaches to the home state, which is required to ensure funds adopt adequate policies and practices necessary to respect human rights. These regulations would fall squarely within a home state's traditional right to regulate despite the indirect impact on host states. The state duty to protect is therefore best understood in this context as attaching to the home state and will be treated as such for the remainder of this article.

\section{Applying the Responsibilities of States and Mutual Funds}

Based on the foregoing discussion, this section analyses the relationship and responsibilities of investors, mutual fund managers and states in addressing the impacts of a mutual fund on human

\footnotetext{
${ }^{190}$ See supra n 194.

191 See Parrish, 'Reclaiming International Law from Extraterritoriality' (2009) 93 Minnesota Law Review 815 at 856-860; see also Bernaz, supra n 179 at 509.

192 See Bernaz supra n 179 at 509.

${ }^{193}$ See Joseph, Corporations and Transnational Human Rights Litigation (2004) at 12.
} 
rights. There are two issues that are particular to the mutual fund industry. First, funds are designed to both attract and protect investors who may be uneducated about the market and the impact of their decisions. As a result, the influence of the fund's investors is likely to be limited. Second, as explained above, mutual funds do not have 'employees' acting on their behalf, only external managers, advisers and service providers, raising questions about the role of the mutual fund manager. This section addresses these issues in turn before considering the types of regulations states may need to adopt to fulfill their duty to protect.

\section{A. The Effectiveness of Investor Activism}

In ordinary companies, investors can play a key role in addressing human rights by using their influence as shareholders to encourage companies to avoid, mitigate and redress adverse human rights impacts. Shareholders can draw attention to human rights issues through shareholders proposals, ${ }^{194}$ a practice that has proven fundamental for placing human rights issues on the schedule of US corporations. ${ }^{195}$ UK shareholders have the right to ask the directors of the company to call for a general meeting. ${ }^{196}$ Shareholder proposals gained prominence during the successful anti-apartheid divestment movement of the 1970s and 1980s, ${ }^{197}$ and shareholders continue to successfully advance proposals and to advocate on human rights. ${ }^{198}$

Unlike in traditional businesses, investor engagement with mutual fund managers is unlikely to be effective. ${ }^{199}$ The fund is set up so that managers can act swiftly, while trustees ensure that the substance and process of the manager's decisions are appropriate in light of the

\footnotetext{
${ }^{194}$ See Horrigan, Corporate Social Responsibility in the 21st Century: Debates, Models and Practices Across Government, Law and Business (2010) at 180.

195 See ibid.

${ }^{196}$ Company Act 2006, Part 13. 303. There are technical requirements before shareholders can force such meetings. See ibid at Part 13, 303, 304.

${ }^{197}$ See Bettignies and Lépineux, Finance for a Better World: The Shift Toward Sustainability (2009) at 80.

${ }^{198}$ Mullerat, Corporate Social Responsibility: The Corporate Governance of the 21st Century, 2nd edn (2011) at 249.

${ }^{199}$ See Baker et al., supra n 22 at 413.
} 
investment objectives. ${ }^{200}$ Investors often choose mutual funds to lessen the burden of managing these investments. ${ }^{201}$ The 'right to exit' ${ }^{202}$ means investors can quickly leave a fund without facing significant financial impacts. ${ }^{203}$ Together, these factors suggest that investors are unlikely to attempt to influence the fund management or to seek to ensure the fund respects human rights on a long-term basis.

Despite the limited likelihood of investor activism, there is a business case for mutual funds to consider human rights. A company's failure to respect human rights can have adverse financial consequences on the company, which in turn can decrease the value of the company's shares. ${ }^{204}$ A failure by fund managers to consider the human rights implications of their investments has the potential to undermine confidence in the fund.

\section{B. The Role of Managers and Trustees in Mutual Fund Due Diligence}

In this section, we offer suggestions as to how to operationalize the UNGP in the mutual fund industry. Because the issue has not been addressed directly before, we draw on the standards established by the UNGP to suggest practical ways in which fund managers can implement their human rights responsibilities. We focus on four areas: the responsibility of funds to incorporate human rights into their investment objectives; how managers can set priorities for due diligence; how to design and implement the due diligence; and finally, the potential that the responsibility to respect may require a fund to divest from an investment.

\footnotetext{
${ }^{200}$ See Turner, supra n 180 at 105.

${ }^{201}$ See Morley and Curtis, 'Taking Exit Rights Seriously: Why Governance and Fee Litigation Don't Work in Mutual Funds', (2010) 120 Yale Law Journal 84 at 102.

${ }^{202}$ See supra n 31 and accompanying text.

${ }^{203}$ See Brandl, Money, Banking, Financial Markets and Institutions (2016) at 470; See also Jones, supra n 87 at 29.

${ }^{204}$ See e.g. Lifsher, 'Unocal Settles Human Rights Lawsuit Over Alleged Abuses at Myanmar Pipeline,' LA Times, 22 March 2005. [last accessed 20 August 2016]; Chambers, 'The Unocal Settlement: Implications for the Developing Law on Corporate Complicity in Human Rights Abuse,' Human Rights Brief (2005).
} 
Generally, the burden for complying with the UNGP falls on a business's internal leadership - senior managers, directors and employees - who are employed by or for the benefit of the company and who are expected to adopt policies and procedures that embed respect for human rights throughout the organization. ${ }^{205}$ As explained above, mutual funds lack any internal employees. ${ }^{206}$ One might suggest that the lack of internal employees means that there is an open question about human rights responsibilities in the context of mutual funds, or that the responsibility to respect should default to the investors. This would be an inappropriate reading of the UNGP. Mutual fund managers - who as a separate corporate entity also have their own responsibility to respect human rights - technically sit outside the fund, but are directly responsible for its conduct. Only the manager can make decisions about the fund's operations and conduct - a structure that is necessary for protecting the purpose of mutual funds ${ }^{207}-$ and the manager should therefore carry the responsibility for human rights due diligence. Below, we offer some suggestions as to how they can do this.

While the managers have the primary role, trustees are obligated to ensure managers are conducting themselves appropriately in light of the fund's obligations and responsibilities. ${ }^{208}$ As with managers, the trustees, as a separate corporate body, have both a responsibility when operating on behalf of the fund, and their own distinct human rights responsibility. ${ }^{209}$ The trustee's responsibility is not to substitute their judgement for the manager's, but to supervise the manager's conduct of operations and ensure that the manager gives due consideration to relevant factors while implementing the investment objectives. ${ }^{210}$ The recommendations below are

\footnotetext{
${ }^{205}$ See UNGP, supra n 12 at Principles 16-17 and accompanying commentary.

${ }^{206}$ See supra n 66-69 and accompanying text.

${ }^{207}$ See supra n 25-34 and accompanying text.

${ }^{208}$ See Turner, supra n 180 at 105.

${ }^{209}$ See UNGP, supra n 12 at Principle 11, Commentary and Principle 14.

${ }^{210}$ See Turner, supra n 180 at 105.
} 
primarily aimed at managers but simultaneously inform the trustees' role and set operational standards for which trustees should hold managers accountable.

\section{(i) Incorporating human rights into investment objectives}

The commitment to human rights due diligence should be incorporated into funds' investment objectives. ${ }^{211}$ While normally the UNGP expect businesses to adopt a 'policy commitment', which suggests a non-binding standard, ${ }^{212}$ the mutual fund's investment objectives dictate what the fund managers can do and what issues must guide their considerations and their investments. $^{213}$ The specificity of these objectives means that there is limited flexibility for fund managers to operate outside the objectives, or to include other factors into their decisions. ${ }^{214}$ As a result, it is important for managers to ensure a clear commitment to human rights within the investment objectives and to specify the contours of that commitment.

To offer clarity for both the manager and the investors, investment objectives should identify how managers define human rights, what data and information they will use to evaluate human rights impacts, as well as the range of actions that can be taken in response to negative impacts and the timeline for implementing those actions. ${ }^{215}$ Without explicit criteria, managers may feel constrained in their consideration of human rights, or they may feel it is acceptable to sacrifice human rights compliance in favour of other outcomes. The inclusion of clear standards in the investment objectives can counteract both of these impulses and oblige the fund to consider human rights as part of the decision-making process. As is discussed below, a fund may not be able to conduct due diligence on all of its investments because of limited personnel or

\footnotetext{
${ }^{211}$ See UNGP, supra $\mathrm{n} 12$ at Principle 16.

${ }^{212}$ See supra n 127.

${ }^{213}$ See supra $n 84$.

${ }^{214}$ Collective Investment Schemes Sourcebook 2014, coll 4.2.5.

${ }^{215}$ Similar recommendations have been made for banks. See Banktrack, Banking with Principles, supra n 10 at 7-8.
} 
finances. A manager should develop, and identify in the investment objectives, criteria for establishing priorities within the due diligence process. We suggest a four-prong approach for setting priorities below.

\section{(ii) Establishing priorities}

Mutual fund managers already engage in comprehensive risk management, using information from a variety of sources to assess potential risks and establish policies aimed at avoiding or mitigating those risks to the fund. ${ }^{216}$ This process should be replicated for human rights, only this time the focus must be on the risks posed not to the fund but to third parties. ${ }^{217}$ Not all mutual funds, and not all individual investments, will have an equal impact on human rights. Additionally, mutual funds operate with a small number of associated personnel, ${ }^{218}$ and those individuals need to be able to respond quickly to fluctuations in the market, making it unrealistic to expect robust due diligence for each investment. The UNGP make it clear that the process for due diligence can and should be altered because of the size of a business. ${ }^{219}$ Managers can consider the size of the fund - as measured by its financial value - as a relevant factor when designing an appropriate due diligence process. This does not mean that smaller firms or funds can ignore human rights, but rather that the recommendations that follow can be scaled up or down to meet the abilities of the fund itself.

Similarly, limited human rights compliance by states and other businesses means mutual fund managers may not be able to immediately, fully meet their responsibility to respect. When practical or budgetary constraints prohibit full compliance with economic, social and cultural

\footnotetext{
${ }^{216}$ See e.g. Collective Investment Schemes Sourcebook 2014, coll 5.6.16; Investment Company Act of 1940, s 64 (b).

${ }^{217}$ See Van Ho, “Due Diligence" in "Transitional Justice States": An Obligation for Greater Transparency?' in Černič and Van Ho, supra n 39 at 240-241.

${ }^{218}$ See supra $\mathrm{n}$ 52-63 and accompanying text.

${ }^{219}$ UNGP, supra $n 12$ at Principle 17(b).
} 
rights, CESCR has found states are bound by certain immediate ('minimum core') obligations, while full compliance may come later. ${ }^{220}$ A similar standard seems appropriate here. While mutual funds may not be able to fully meet their responsibility to respect, they should establish policies and procedures that allow them to regularly increase their compliance.

Managers should employ human rights advisers to consult on the design of the due diligence process. ${ }^{221}$ The UNGP indicate that seeking and employing professional advice on human rights issues is a minimum expectation on businesses. ${ }^{222}$ Without adequate advice and information, it is impossible to meet the due diligence standard in the UNGP. Separately, trustees should employ their own independent human rights experts to examine the process employed by the manager. A careful balance needs to be struck here as the question for a trustee's human rights experts must not be whether they would have made a specific investment, but rather whether the manager, both procedurally and substantively, is adequately considering human rights and whether the process for addressing risks is capable of appropriately capturing and conveying those risks.

Managers who operate several funds can use a single due diligence process for multiple funds and, based on the UNGP, may be expected to engage in more serious due diligence regardless of the size of any individual fund. ${ }^{223}$ Managers can also work with other institutional investors, through initiatives like the UNPRI, to determine significant human rights risks. ${ }^{224}$ The responsibility of a manager in this case, or the responsibility of several managers in instances of

\footnotetext{
${ }^{220}$ CESCR, General Comment 3: The Nature of States Parties Obligations, U.N. Doc. HRI/GEN/1/Rev.6 at 14 (2003), at paras 10, 11. See also Saul, et al., The International Covenant on Economic, Social and Cultural Rights: Commentary, Cases and Materials (2014), at 134.

${ }^{221}$ UNGP, supra n 12 at Principles 16 and 23, and accompany commentary.

${ }^{222}$ See supra $n 131$.

${ }^{223}$ See UNGP, supra $n 12$ at Principle 17(b).

${ }^{224}$ See Weber and Watson, 'Human Rights and the Extractive Industry: Why Engage, Who to Engage, How to Engage' Principles for Responsible Investment (2015) at 7.
} 
collaboration, could have implications for issues of liability in cases where remedies are required, but those implications, as with the more general issue of remediation, sit beyond the remit of this article.

Where priorities need to be set, the UNGP indicate that salient risks can be prioritized. ${ }^{225}$ Businesses with physical operations may be able to find common risks throughout its operations and learn from past practices. ${ }^{226}$ But for mutual funds, each new investment is likely to trigger different risks depending on the business, the industry and the state of operations. This means that the "most severe risks ${ }^{, 27}$ may be less clear at the start of the due diligence process for mutual funds than for other businesses. Developing a pragmatic means of prioritizing may therefore be more difficult for financial actors than for other businesses. A four-prong approach may be helpful. First, significant financial holdings suggest a greater potential for the fund to impact human rights and should receive prioritization. Determining which investments are 'significant' will require a case-by-case assessment that takes into account, for example, the fund's investment objectives, the net amount of the investment and the percentage of the fund that is being invested. Second, managers should consider whether the targeted industry, state, or individual business is known for severe human rights impacts. While the UNGP are premised on the belief that all businesses can impact human rights, some industries, companies and states have a history of serious human rights impacts or violations. ${ }^{228}$ Fund managers should use past allegations of abuse to help set priorities for new due diligence. Third, fund managers can

\footnotetext{
${ }^{225}$ UNGP, supra n 12 at Principle 17, commentary.

${ }^{226}$ Ibid at Principle 20.

${ }^{227}$ Ibid at Principle 24.

${ }^{228}$ For example, the extractive industries have often been accused of involvement in serious human rights abuses. See e.g. Woods, 'Engaging the U.N. Guiding Principles on Business and Human Rights: The Inter-American Commission on Human Rights and the Extractive Sector' (2015) 12 Brazilian Journal of International Law 571 at 578. On states, see e.g. Human Rights Atlas, Human Rights Atlas, available at: http://www.humanrightsatlas.org [last accessed 5 December 2017].
} 
undertake a more limited review for any investments that do not raise particular concerns under first or second prongs. Finally, if a limited review suggests significant problems with an investment, a more in-depth due diligence is needed, even if the size of the investment is not significant. All investments should get some due diligence, but they do not all need to have the same due diligence. Setting priorities can help managers better engage with due diligence appropriate to the size and scale of their operations.

\section{(iii) Undertaking due diligence and mitigating impacts}

In carrying out human rights due diligence, managers should again utilize human rights experts to inform their decisions. ${ }^{229}$ Fund managers should use available information to determine the risks posed to the human rights of third parties by a company or state's operations, to identify strategies for mitigation and to decide whether the fund is likely to be able to influence the company or state to better respect human rights. ${ }^{230}$ The due diligence process should occur before a new investment is made, if possible, and the findings should be reviewed on an ongoing basis so that new information and risks continually inform managers' decisions. ${ }^{231}$

Determining the 'right' sources to consult can be difficult. When investing in state bonds or state-owned companies, managers should consider information available through public disclosures, including reports developed by states and civil society for the UN human rights bodies and procedures, as well as the responses and recommendations of those bodies. ${ }^{232}$ When investing in corporations or other funds, managers should review company disclosures. Since, unlike a bank, a mutual fund is unable to delineate where its money goes once it makes an

\footnotetext{
${ }^{229}$ UNGP, supra n 12 at Principle 18(a).

${ }^{230}$ See Van Ho, Due Diligence, supra n 218 at 240-241; UNGP, supra n 12 at Principle 19(b).

${ }^{231}$ See UNGP, supra $\mathrm{n} 12$ at Principle 17 and accompanying commentary.

${ }^{232}$ These processes and bodies include the Universal Periodic Review, the UN treaty bodies, as well as special procedures established by the Human Rights Council.
} 
investment, a mutual fund's due diligence must take account of the corporation or the state as a whole. Unfortunately, as UNPRI signatories have experienced, companies often fail to recognize their human rights responsibilities or fail to report on their practices in a substantial and complete way. ${ }^{233}$ Relying exclusively on corporate reporting is therefore unlikely to produce meaningful or actionable information and managers should consider news reports and information from nongovernmental organizations, that addresses the individual entity, the industry generally and the human rights situations in those states in which the targeted company frequently operates. This is not an exhaustive list of sources to consult, as new information will come to light on an ongoing basis. It is therefore probably less important that managers identify the 'right' sources as it is for the manager to take account of sources from different perspectives and to stay abreast of developments within the relevant state, company and industry. The use of human rights advisers may be crucial in helping managers to stay abreast of developments and identify priorities for further due diligence.

After the initial assessments are done, salient risks deserve closer scrutiny. ${ }^{234}$ According to the UNGP, fund managers should discuss these risks with the leadership of the company or state in which they are investing, ${ }^{235}$ and use their leverage to try to affect positive change. ${ }^{236}$ Here, the fund's investment objectives can be useful in demonstrating to states and companies the legal standards required of the fund's managers, and the expectations the company or state needs to meet throughout its operations. The managers should also consult relevant stakeholders, including local and international nongovernmental organizations, trade unions and victim

\footnotetext{
${ }^{233}$ Weber, supra n 129 at 7. See also Global Compact Network Australia, 'Key Trends in Business and Human Rights for 2016: What Business Needs to Know', 12 February 2016, available at: www.unglobalcompact.org.au/2016/02/12/key-trends-business-human-rights-2016/ [ last accessed 5 December 2017].

${ }^{234}$ See UNGP, supra n 12 at Principle 18 and accompanying commentary.

235 See ibid.

${ }^{236}$ Ibid at Principle 19 and accompanying commentary.
} 
advocacy groups. ${ }^{237}$ These consultations should be aimed at gathering information about the impact of the company and the company's mitigation techniques. ${ }^{238}$ Based on the information secured in these meetings, the mutual fund manager needs to determine whether to invest, refrain from investing, or divest their holdings.

\section{(iv) Diverting or divestment may become a necessity}

As noted above, the responsibility to respect suggests that mutual fund managers should prioritize investments in companies with strong human rights standards, and as they can move their investments into such companies and away from companies with negative human rights impacts. ${ }^{239}$ If a fund attempts but fails to affect change within a targeted company, the manager must consider how to mitigate the fund's impacts. ${ }^{240}$ Here, the difficulty with finding investments, either corporations or states, with strong human rights records becomes important. While mutual fund managers are currently unlikely to avoid human rights impacts by investing only in 'good' companies or states, where an impact is serious or sustained and the fund is unable to influence or secure changes the responsibility to respect may become a responsibility to divest. ${ }^{241}$ This is the corollary to the conclusion that fund managers should prioritize investments with strong human rights compliance; businesses and states with negative human rights records need to be avoided. A complete discussion and analysis of divestment as a duty is beyond the scope of this article but scholarly analysis and practical discussion on this issue is necessary to guide both fund managers and states.

\footnotetext{
${ }^{237}$ See Ibid at Principle 18 and accompanying commentary.

${ }^{238}$ Ibid.

${ }^{239}$ See supra n 159-160 and accompanying text.

${ }^{240}$ See UNGP, supra n 12 at Principle 19, commentary.

${ }^{241}$ Divest is used here to refer to disinvestment or a reduction in assets due to ethical concerns. Chesterman, supra $\mathrm{n}$ 39 at 588, n. 37.
} 


\section{(v) Concluding observations on the responsibility of fund managers}

We recognize the limitations of these recommendations, which are an imperfect response to the expectations in the UNGP. Without a sufficient number of corporations or states meeting their human rights responsibilities, it is difficult to impose any further immediate duties on mutual funds. In order to give effect to both the purpose of a mutual fund and the demands of human rights, a balance needs to be struck until a stronger system of human rights reporting on corporate and state impacts is developed. When corporate human rights compliance and reporting reaches appropriate thresholds, both in number and substance, the responsibilities attached to mutual funds should correspondingly increase. Greater compliance with the responsibility to respect in other industries will increase the responsibility on mutual funds to divert their investments from non-compliant businesses and states to those businesses or states that provide robust compliance mechanisms and a strong record of due diligence.

A more significant barrier is, of course, garnering the necessary will to act on this issue. It seems fairly obvious that the Thun Group's proposed application of the UNGP is borne not out of a desire to avoid human rights responsibilities but to avoid legal liability when banks prioritize profits over human rights compliance. The Thun Group itself recognizes that there is an expectation on banks to undertake human rights due diligence. ${ }^{242}$ What the banks argue is that their failure to abide by their responsibility should not lead them to incur legal liability for contributing to an impact caused by a client's actions. ${ }^{243}$ Inevitably, the proposals here will similarly face resistance from mutual fund managers. ${ }^{244} \mathrm{We}$ wish to stress that the proposals here

\footnotetext{
${ }^{242}$ Thun Group, 2017 Discussion Paper, supra n 142 at 3.

${ }^{243}$ Ibid., at 6.

${ }^{244}$ Financial advisers in the US actively oppose development of a 'Fiduciary Rule,' which would oblige them to act in their clients' best interest. See e.g. Pavia, 'Trump delays Controversial Fiduciary Rule for Advisors', CNBC, 3 February 2017, available: at www.cnbc.com/2017/02/03/trump-delays-controversial-fiduciary-rule-for-advisors.html [last accessed 5 December 2017]; Leonhardt, 'Inside Wall Street's Secret War on American Investors', Time,
} 
take into account the peculiarities of the mutual fund industry, but they do not ask more of the mutual fund industry, or financial actors as a whole, than the singular expectation equally applied to all industries and businesses: implementation of the 'responsibility to respect'.

\section{The Need for State Action}

The state duty to protect appears most important when market conditions are unlikely to generate necessary change. Because mutual funds are intended, in part, to assist 'unsophisticated' investors, resulting in limited shareholder engagement, market conditions alone are unlikely to generate change. It is therefore necessary to again consider the state duty to protect, which, as noted above, we treat as an obligation of the home state. ${ }^{245}$ In this section, we outline recommendations for home states in terms of regulations appropriate for the mutual fund industry. These recommendations mirror those for the funds themselves in order to ensure that the two work together to close compliance gaps that currently exist.

Neither the UK nor the US regulations that require managers to adopt comprehensive risk management processes, assess potential risks or problems in advance and establish proper policies to avoid those risks or minimize their impacts, reference the fund's impact on human rights. ${ }^{246}$ States should require funds to employ due diligence standards based on objective criteria that address the impact of the fund on human rights and to identify those standards within the fund's investment objectives. Mutual fund managers should be expected to assess, monitor and periodically review the adequacy and effectiveness of the human rights risk management policy, and trustees should be required to oversee this process. Finally, states should consider

updated 3 February 2017, available at: time.com/money/4640730/wall-street-fights-fiduciary/ [ last accessed 5 December 2017].

${ }^{245}$ See supra section 3.C.

${ }^{246}$ Collective Investment Schemes Sourcebook 2014, coll 5.6.16; Investment Company Act of 1940, s 64 (b). 
whether, when and how to mandate divestment from entities where there is a pattern of serious abuse.

States should require regular reports to shareholders that address (1) the steps taken in furtherance of the fund's responsibility to respect, (2) significant human rights risks in the portfolio, (3) the human rights impacts of significant holdings, and (4) the steps the manager will take to mitigate or remediate any impacts. Reporting regulations, however, are of limited use and do not on their own fulfil either a fund's responsibility to respect or the states' duty to protect. They are recommended as a first step specifically because many businesses in which funds might invest do not yet meet their own human rights responsibilities, and many states do not yet effectively regulate businesses for the protection of human rights. As states and other industries increase their own human rights compliance, states should increase the requirements on mutual fund managers, ensuring that they not only report on their human rights standards, but also undertake clear and increasingly strong due diligence and mitigation techniques.

To encourage and secure compliance, states should also develop both 'sticks' and 'carrots' for fund managers. ${ }^{247}$ Among the 'sticks' might be regulatory fines or limited access to markets if a fund has inadequate investment objectives or fails to meet the investment objectives on human rights. Among the carrots could be early access to preferred state bonds for robust assessment programs or for establishing or participating in a network of institutional investors that work together on business and human rights due diligence.

As with the recommendations for managers, these are admittedly imperfect solutions to a problem posed by the limited compliance of other states and business with the UNGP.

\footnotetext{
${ }^{247}$ The need for both 'sticks' and 'carrots' was highlighted in the resignation letter of Puvan Selvanathan from the UN Working on Business and Human Rights. See Selvanathan, 'Letter to the President of the Human Rights Council' at 2, 15 December 2015, available at: business-

humanrights.org/sites/default/files/documents/Letter $\% 20$ to $\% 20$ the $\% 20$ President $\% 20$ HRC.pdf [last accessed 5 December 2017].
} 
Introducing a regulatory framework, however, is a significant step forward. Requiring compliance standards for mutual funds has the additional benefit of using market forces to encourage non-financial businesses to improve their human rights compliance. States should continually return to and reassess their mutual fund regulations as both human rights compliance in the market and state regulation of other industries expands.

\section{Conclusion}

This article has examined how states and mutual funds can better respond to the human rights impacts of the mutual fund industry. Addressing the various market actors is an important step to closing the governance gap that currently exists in regards to the financing of abusive states and corporations. This article has raised the issue of mutual funds with the hope of opening the discussion beyond banks and project financing. It has focused on the state duty to protect and the business responsibility to respect with the expectation that future scholarship will consider the issue of remediation. ${ }^{248}$

The issues raised by the impact of mutual funds on human rights are complex. Unlike a traditional, non-financial business, mutual funds are unlikely to cause human rights harms. Instead, they will only contribute to human rights impacts through the financing of others' actions. As explained in this article, however, the UNGP use a lower threshold for 'complicity' than what is currently employed in international criminal law, suggesting that mutual funds have a responsibility to respect even when the immediate cause of the impact is not directly attributable to the fund. Where an impact is unavoidable, businesses, including mutual funds, can use their leverage to push for change while mitigating their contribution to the impact.

\footnotetext{
${ }^{248}$ Discussion surrounding Thun Group's recent discussion paper demonstrates the need for such scholarship. See supra n 157.
} 
Unfortunately, unlike banks and other financial entities, mutual funds are unable to distinguish between corporate entities within a particular group or between projects operated by a single business. As a result, they have less leverage, on their own, to demand that businesses conduct human rights assessments or change their policies, and fewer options for mitigating their impact.

This article offers a few suggestions for how states and mutual funds can respond to the industry's human rights impacts. The burden for ensuring the responsibility to respect falls on fund managers and trustees, despite the fact that they both technically sit outside the fund's corporate or trust structure. Trustees should hold managers accountable for establishing appropriate policies and procedures in regards to human rights. In turn, managers must assess, manage, mitigate and remedy human rights impacts. Finally, home states should be the dutybearers in regards to the obligation to protect and must establish clear regulatory standards for mutual funds, managers and trustees.

Because of limited human rights compliance in other industries and by states, it will be difficult for managers or states to immediately implement fully their UNGP responsibilities. This article recommends certain steps that can be undertaken immediately, with the intention of a progressive realization of the fund's responsibilities. Mutual fund managers and trustees can begin by hiring human rights advisers to help develop due diligence standards and include human rights language into new investment objectives. When they have human rights due diligence practices in place, managers can prioritize for investment those states and companies that take human rights seriously. Trustees can check and supervise the work of managers by employing independent human rights experts to ensure that the due diligence process developed is procedural and substantively sound. As respect for human rights becomes more systematized and as states better regulate other industries, mutual fund managers can be expected to undertake 
more extensive due diligence. Simultaneously, states can adopt regulations requiring fund managers to report on their human rights standards and introduce regulations requiring managers to directly incorporate human rights standards are into the investment objectives. The process of ensuring the mutual fund industry fully complies with the UNGP responsibility to respect will take time. This should not be a deterrent to taking these immediate actions that are necessary for respecting and protecting human rights.

\section{ACKNOWLEDGMENTS}

The authors are grateful to Sabine Michalowski, Anil Yilmaz-Vastardis, Nadia Bernaz, Sheldon Leader, Youseph Farah, Ebba Lekvall and the anonymous review for comments on earlier drafts. This research was undertaken while Dr Van Ho was a post-doctoral researcher and Assistant Professor at INTRAlaw Centre, Aarhus University (Denmark). 